\title{
New Business Strategy for Social Enterprise in Facing the Pandemic of COVID-19
}

\author{
Isep Paozi and Melia Famiola
}

\section{ABSTRACT}

The coronavirus (COVID-19) pandemic has changed people's lifestyles in various aspects of life. In the midst of such changes, Aqiqah Al-Hilal as the provider of Aqiqah catering services in Indonesia which provides packages of lamb dishes needs to make several adaptations so that the market does not leave it.

Aqiqah Al-Hilal is a social enterprise engaged in food catering services where the proceeds from its business are fully used to finance the education of some orphans in Indonesia. Nowadays, Aqiqah Al-Hilal faces problems in terms of decreasing turnover from 2020 until now. Based on data obtained from the Al-hilal financial manager. When the Covid-19 Pandemic Emergency began in March 2020 was announced by the Indonesian government, Aqiqah Al-Hilal experienced a significant decrease in turnover or company income

The purpose of this research is to identify the problems faced by Aqiqah Al-Hilal in carrying out their current business strategy and to propose the new business strategy for Aqiqah Al-Hilal as a social enterprise that must survive in running its business. This research uses a qualitative method with a single case study approach and uses interviews, observation, FGD, and documentation as data collection techniques.

Based on the analysis of the position of Aqiqah Al-Hilal in the current situation will determine the strategies that need to be taken to survive the pandemic. The results of the IE matrix show that Aqiqah Al-Hilal is in the Hold and Maintain position. In the "Hold and Maintain" position, the best strategy to do is market penetration and product development. These related details are explained clearly in this paper.

Keywords: Aqiqah Al-Hilal, Social Enterprise, New Business Strategy.

\section{INTRODUCTION}

\section{A. Background}

The COVID-19 Pandemic has almost had a significant impact on various sectors, not only health. The economic sector has also experienced a serious impact due to the coronavirus pandemic 19. Restrictions on community activities affect business activities which in turn have an impact on the economy (Iswanto, 2020).

Almost all business industries from sharing sectors have become disrupted, this is a very tough challenge for the future, where in addition to facing the coronavirus pandemic, the business activities are also faced with changes in the behavior of people from all walks of life.

The executive Director of the Head of the Bank Indonesia Communication Department, Onny Widjanarko, said that the decline in business activities occurred in all economic sectors. The deepest declines were in the manufacturing sector, the trade sector, hotels and restaurants, and the services sector (Nurul Ulya, 2021). This was mainly due to reduced demand and supply disruptions due to COVID-19. The most affected business sector is MSMEs. This is felt
Submitted : September 08, 2021

Published : February 11, 2022

ISSN: $2507-1076$

DOI: $10.24018 /$ ejbmr.2022.7.1.1097

Isep Paozi *

Bandung Institute of Technology,

Bandung, West Java, Indonesia.

(e-mail: isep_paozi@sbm-itb.ac.id)

Melia Famiola, Ph. D.

Bandung Institute of Technology,

Bandung, West Java, Indonesia.

(e-mail: melia.famiola ${ }^{\circledR}$ sbm-itb.ac.id)

*Corresponding Author

significantly by Micro, Small, and Medium Enterprises (MSMEs) actors who are experiencing an economic crisis. The reason is the decline in people's purchasing power due to the COVID-19 pandemic also greatly affects the sustainability of MSME businesses. The economic crisis experienced by MSMEs can unwittingly become a threat to the national economy. Therefore, guidance and assistance for MSME players during the pandemic need to be the concern of many sectors, especially government agencies.

One of the MSMEs that was affected was Aqiqah AlHilal. It is a social enterprise as business unit managed by Al-Hilal Foundation where the profits are used to fund the social program. Aqiqah is an Islamic terminology which means an animal that is slaughtered at the birth of a child (Islamicaid, 2021). In Indonesia, Aqiqah has been business opportunity as Aqiqah catering service. Instead of slaughtering goats and cooking them themselves, many choose to use Aqiqah catering services. That is why, this line of business is also called a great opportunity. The majority of the Indonesian population is Muslim, and it is recommended when having children to perform Aqiqah (Jay, 2021). 
Nowadays, Aqiqah Al-Hilal faces problems in terms of decreasing turnover from 2020 until now. Based on data obtained from the Al-hilal financial manager. When the Covid-19 Pandemic Emergency began in March 2020 was announced by the Indonesian government, Aqiqah Al-Hilal experienced a significant decrease in turnover or company income (Internal data of Aqiqah Al-Hilal, 2021).

Therefore, to deal with the above conditions, a new business strategy is needed so that Aqiqah Al-Hilal can maintain its business and can adapt quickly to various kinds of changes.

\section{B. Business Overview and Its Challenge}

Aqiqah Al-Hilal is a business unit of the Institute that nurtures and empowers orphans, namely Al-Hilal Islamic boarding School under the auspices of the Al-Hilal Foundation, which was originally this social institution nurturing, caring, educating, and fostering orphans since 2004 until now. The number of orphaned students ranges from about 434 students spread across four areas in west java, Indonesia (Internal data of aqiqah Al-Hilal, 2021).

The core business of Aqiqah Al-Hilal is catering services for Aqiqah. Aqiqah Al-Hilal focuses on providing the Aqiqah package which consists of processed lamb in the form of satay and curry.

Aqiqah Al-Hilal has business activities including the following:

1) Ordering sheep/lamb: This order is directly ordered to breeders who have collaborated with Aqiqah Al-Hilal.

2) Slaughter of sheep: slaughtering sheep in Aqiqah AlHilal is carried out directly.

3) Cooking lamb: The processing of lamb into satay and curry is carried out in the Aqiqah Kitchen by experienced chefs who already have standard operating procedures for cooking lamb, especially for Aqiqah Al-Hilal.

4) Packaging Aqiqah package; This activity was carried out at the Aqiqah kitchen by a kitchen team consisting of orphaned mothers from the Al-Hilal Islamic boarding school and members of the general public who were deliberately empowered by Aqiqah Al-Hilal.

5) Delivery of Aqiqah packages to customers; The Covid-19 pandemic has certainly made many people have to get used to adapting, including in the implementation of Aqiqah even in simple situations without any crowds. Moreover, Aqiqah is interpreted as gratitude for the birth of the baby. Usually, the implementation of Aqiqah invites many people, but because of the pandemic, these activities are prohibited to prevent transmission. Holding an Aqiqah event will be very vulnerable if you invite several guests. This is because babies are very susceptible to disease. So, during the Covid-19 pandemic, it is better to find an alternative to celebrate Aqiqah. Aqiqah Al-Hilal catering services need to be creative in this regard so that Aqiqah services can still be offered to potential customers.

\section{Research Objectives}

Based on the background of the problems and business issues described above, the research objectives of this study are to analyze the actual problems faced by Aqiqah Al-Hilal in running their current business strategy and to propose the new business strategies that the company will undertake to adapt, survive in this situation.

\section{LITERATURE REVIEW}

\section{A. Business Strategy}

Business strategy is defined as a comprehensive commitment to be able to utilize and increase resources into capabilities for superior competencies so that competitive advantages can be obtained from one market product (Wandebori, 2019, p. 69).

Every company has a business strategy, so it is the most important strategy compared to other strategies, such as corporate strategy and functional strategy. The business strategy carried out by the company certainly has objectives and benefits. The business strategy objectives are as follows for business continuity in the sense that a company that carries out a unique business strategy and good marketing methods will make its business survive (Joewono, 2012, p. $3)$.

Meanwhile The benefits of a business strategy include a guide in building a business, of course, it can help businesspeople to be able to find out the direction of their business development. The benefits of a business strategy can also improve organizational capabilities in facing various challenges ((Joewono, 2012, p. 4).

\section{B. Internal Analysis}

All organizations have strengths and weaknesses in the functional areas of the business. No business is as strong or weak in all areas. Internal strengths/weaknesses, coupled with external opportunities/threats and a clear mission statement, provide the basis for setting goals and strategies. Goals and strategies are set with the aim of exploiting strengths and overcoming internal weaknesses. competencies that cannot easily imitate or match the strength of the company which is a special competency (Aaker, 2012, p. 124).

\section{External Analysis}

The purpose of the external analysis is to develop a limited list of opportunities that can benefit a company and the threats that must be avoided. As the term-limited implies, an external audit does not aim to develop a complete and comprehensive list of every factor that can affect the business, but rather to identify the important variables that offer an action response. Companies must be able to respond offensively or defensively to these various factors by formulating strategies that can take advantage of external opportunities or minimize the impact of potential threats. Defensive strategy is a company's defensive strategy that aims to reduce the likelihood of being attacked by competitors, deflecting attacks in a direction that is not harmful or reducing its intensity. Meanwhile, the offensive strategy is more aimed at reaching and acquiring new customers, to increase market share, sales, and the number of customers (Aaker, 2012, p. 84). 


\section{Social Enterprise and COVID-19}

The purpose of social enterprises is to serve as a sustainable tool for reducing social problems. The finances of social enterprise must be secured especially when the crisis hits. Therefore, the activities that generate commercial income should be used and strengthened by social enterprises (Rasheda, 2020, p. 7). One of the impacts of the pandemic on the social enterprise sector should be viewed with an emphasis on resilience strategies implemented by social enterprises and how innovations are applied to address the problems caused by COVID-19 (Rasheda, 2020, p. 8).

Related to the strategy, in order to alleviate the problems caused by COVID-19, social entrepreneurship and value cocreation strategies need to be used to generate positive change (Ratten, 2020).

\section{MethodolOGY}

\section{A. Research Framework}

The author will use the IE matrix framework to determine the right strategy used by Aqiqah Al-Hilal in running a new business strategy. IE matrix aims to see the position of the company and obtain a more detailed business strategy at the business unit division level. The IE matrix is divided into three main areas with different strategic implications (Wandebori, 2019, p. 192).

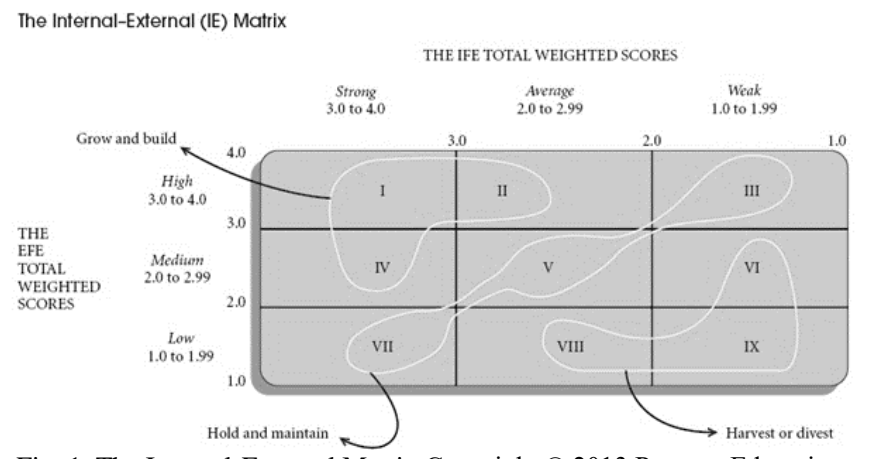

Fig. 1. The Internal-External Matrix Copyright (C) 2013 Pearson Education, Inc. publishing as Prentice Hall (The Internal-External Matrix Pearson Education, Inc. publishing (C) 2013).

The three main areas with implications for these different strategies are as follows:

a. Cells I, II, IV Can carry outgrowth and build strategy. Commonly applied strategies are intensive strategies (market penetration, product development) or integrative strategies (backward, forward, horizontal integration).

b. Cells III, V, VII Can carry out hold and maintain strategy. Common strategies are market penetration and product development.

c. Cells VI, VIII, IX Can carry out a harvest or divest strategy. Common strategies applied are divestment, diversification, conglomerate, and liquidation strategies.

\section{B. Research Method}

This research uses a qualitative method with a case study approach and the data collection techniques used in this research include interviews, observation, FGD, and documentation. Qualitative research is a scientific study that aims to understand a phenomenon in natural social contact by promoting a deep communication interaction process between researchers and the phenomenon under study (Moleong, 2011, p. 6).

The sources of data used in this study using primary and secondary data. Primary data sources used in this research include the information from Aqiqah Al-Hilal Stakeholder, Al-Hilal Foundation Stakeholders, and Information from AlHilal Customers. Whereas secondary data sources used were written sources such as book sources, scientific articles, the Aqiqah Al-Hilal website, and documents from parties related to Aqiqah Al-Hilal.

\section{FINDING AND ANALYSIS}

\section{A. Internal Analysis of Aqiqah Al-Hilal (Internal Factor Evaluation)}

To understand the Aqiqah Al-Hilal business situation, it is necessary to carry out an internal analysis consisting of its weaknesses and weaknesses related to the resources and value chain activities that create its capabilities. Internal company evaluation can be carried out by one method, namely Internal Factor Evaluation (IFE), which is the best method for analyzing the internal factors of Aqiqah AlHilal.

\section{1) IFE No. 1 (Following Islamic Sharia)}

Aqiqah Al-Hilal is not careless in choosing animals and slaughtering them. animals that are required to slaughter Aqiqah are animals that have the same criteria as sacrificial animals. Aqiqah Al -Hilal chooses a goat or sheep that is healthy and not defective and has a minimum age of half a year. The process of slaughtering the Aqiqah sheep also follows the rules of Islamic law.

\section{2) IFE No. 2 (Tasty \& Delicious)}

Aqiqah Al-Hilal is known by the people of Bandung for its delicious and delicious taste. Due to the strict process of selecting goats and slaughtering them, the meat is cooked with high quality and will not smell. Aqiqah Al-Hilal has a team of reliable chefs who are experienced in the world of hotel catering so that the quality of the food produced has a high taste, delicious and delicious.

\section{3) IFE No. 3 (Free Test Food)}

The team from Aqiqah Al-Hilal is ready to deliver Test Food to the homes of potential customers for free. This is a serious and innovative step from Aqiqah Al-Hilal as a commitment and evidence to convince prospective customers of the superiority of Aqiqah Al-Hilal. Prospective customers can contact the admin of Marketing Aqiqah AlHilal to submit a Free Food Test which will be sent to the address of the prospective customer.

\section{4) IFE No. 4 (Free shipping and guarantee on time)}

As a consumer, getting free shipping (postage) is certainly a pleasure in itself. The shipping cost determined is usually based on the weight and how far the delivery is. As a provider of Aqiqah services, in this case, Aqiqah Al-Hilal does not apply postage for every Aqiqah package offered. Consumers no longer need to pay extra for postage, because all packages offered to apply free shipping throughout Bandung Raya. 


\section{5) IFE No. 5 (Halal Certification from MUI)}

Nowadays, halal certification has become something that must be owned by a business, especially in the culinary field. The inclusion of the halal label from MUI (Indonesian Council of Ulama) is important not only for consumers but also for producers.

Aqiqah Al-Hilal has received this MUI Halal certification from 2018. The MUI halal label provides a sense of security for Aqiqah Al-Hilal consumers. In addition, the MUI halal label is a guarantee that the Aqiqah Al-Hilal products they consume are safe from non-halal elements and are produced in a halal way.

\section{6) IFE No. 6 (There is documentation in each process)}

Documentation in Aqiqah is one of the things that absolutely must be given to consumers of aqiqah. As a trusted Aqiqah service, Aqiqah Al-Hilal documents every process from slaughtering sheep, cooking, packaging to documenting the distribution of Aqiqah if it is distributed directly by Aqiqah Al-Hilal. For consumers, documentation can be a memory for families and children who are Aqiqah later, and for Aqiqah Al-Hilal, documentation is a form of trust to consumers.

\section{7) EFE No. 7 (Healthy and Quality Goat Sheep)}

Aqiqah Al-Hilal has a reliable supplier of sheep. The craftsmen who care for the Sheep \& Goats in Aqiqah AlHilal are very painstaking in caring for the aqiqah animals. The craftsmen who take care of the sheep are very careful about the cleanliness of the drums and the cleanliness of their food. Therefore, the sheep in Aqiqah Al-Hilal are sheep that are healthy, not defective, and of good quality.

\section{8) IFE No.8 (There is no application for ordering, still} manual via Whatsapp)

In dealing with prospective customers, Aqiqah Al-Hilal uses Whatsapp Business. Until now, Aqiqah Al-Hilal does not have an application that makes it easy for prospective customers to order Aqiqah. When confirmed to Aqiqah AlHilal's Marketing Manager, Mr. Welly. Aqiqah Al-Hilal is in the application development stage which can be downloaded on the Playstore or AppStore. He admitted that he was still in the development stage so that the application could make it easier for potential Aqiqah customers in orders and transactions.

\section{9) IFE No.9 (Limited competent chefs in cooking curry)}

A chef or often called a chef is an important element in the culinary business. The chef is in charge of making recipes, determining and measuring ingredients, cooking, and also presenting a delicious dish. However, the limitation of this experienced chef is one of the challenges for Aqiqah Al-Hilal.

\section{B. External Analysis of Aqiqah Al-Hilal (External Factor Evaluation)}

Besides analysis of Aqiqah Al-Hilal's internal factors, it is also important to analyze the outside factors of Aqiqah Al-Hilal's business, especially during a pandemic. The external factors evaluation could give potential factors which can contribute not only as a threat (negative) but also the opportunity (positive) factors. Understanding this potentially could benefit Aqiqah Al-Hilal to mitigate during the pandemic and anticipate opportunities post-pandemic era.

1) EFE No. 1 (The demand for halal and Shariacompliant products is increasing)

Halal food will be an option for people who are concerned with health and safety. Along with new behavior, people also care more about cleanliness. So that halal products are targeted.

Aqiqah Al-Hilal as a quality and professional Aqiqah service provider applies halal product standards by obtaining a halal permit from the MUI.

2) EFE No. 2 (Good taste quality makes repeat orders from consumers)

For Aqiqah Al-Hilal, in running a culinary business the most important and must be maintained is the taste of the food. Maintaining this taste is the key to the success of Aqiqah Al-Hilal. Although they continue to innovate in terms of food, the teams at Aqiqah Al-Hilal, especially the kitchen team, continue to strive to maintain the characteristics from the very beginning of this Aqiqah AlHilal.

\section{3) EFE No. 3 (Attract consumers not to issue postage)}

One of the attractions that Aqiqah Al-Hilal offers is that it offers free shipping for every Aqiqah package. It could be said that Aqiqah Al-Hilal applied this method to attract buyers. This proves that free postage promos are very effective in increasing business sales. Sometimes, potential customers take postage as a consideration in buying a product.

By eliminating shipping costs, Aqiqah Al-Hilal aims to make buyers only need to pay the price of the goods, in this case, the Aqiqah package they buy. This free postage promo is in great demand and can win the market.

\section{4) EFE No. 4 (Belief in the quality of lamb meat makes} consumers not hesitate to take action in al-Hilal)

Lamb meat is a source of high protein which is relatively rarely included in everyday cooking in Indonesia. In fact, lamb meat is relatively easy to find in Indonesia and very easy to create in everyday dishes. Apart from being rich in protein, lamb meat is also a source of other, no less important nutrients such as iron, zinc, and vitamin B12. To ensure nutrition, meat quality is important when choosing meat for consumption.

\section{5) EFE No. 5 (Uncertainty pandemic periods)}

The coronavirus has spread throughout the world for more than one year, the first case was announced at the end of December 2019. The COVID-19 pandemic has not ended until today. New cases are still increasing in almost all countries. The current state of the pandemic seems to provide uncertainty about when it will end. This uncertainty triggers a condition called a fatigue pandemic or a fatigue pandemic. Uncertainty when the pandemic will end, changes in consumer behavior, and the still-sluggish global economy have contributed to the world economic recovery. This is a threat to industry and business, including the culinary industry, one of which is Aqiqah Al-Hilal. 


\section{6) EFE No. 6 (Prohibition of gathering causes potential} customers to postpone Aqiqah)

During the COVID-19 Outbreak. The government has prohibited people from gathering for fear of worsening the spread of the coronavirus or COVID-19. Including the prohibition of worship or other activities. The government through the COVID-19 Handling Acceleration Task Force can take a firm stance by imposing sanctions. This includes calls for not gathering in large numbers even though it is related to religious worship activities. This is a challenge in itself for culinary businesspeople, one of which is Aqiqah Al-Hilal, wherein Aqiqah, thanksgiving is usually done by gathering many people to pray for children who are Aqiqah.

\section{7) EFE No.7 (Consumers can switch to other companies)}

Currently, business competition is getting tougher, so it must be dealt with in a healthy manner and in accordance with existing regulations. It is normal for a business to have competitors or competitors. What needs to be done in winning the competition is to think and implement a special strategy so that consumers can switch to using your product instead of competitors. Aqiqah Al-Hilal in this case continues to strive to maintain its business by implementing new strategies in running its business.

\section{Variables of Swot Analysis}

SWOT analysis is used to identify the internal factors, also external factors. Therefore, those factors were divided into different categories which suited the condition. From SWOT's table, the summary is there are 7 strengths, 3 weaknesses, 4 opportunities, and 3 threats. Those factors are still qualitative factors that still are not clear enough what the impact it is for Aqiqah Al-Hilal. Therefore, the next step after this is a quantification of SWOT variables.

\section{Quantification of SWOT}

The qualitative data from chapter $\mathrm{V}$ will be used in this chapter to determine the total score of IFE (Internal Factors Evaluation) and EFE (External Factors Evaluation) These two scores will determine the position of Aqiqah Al-Hilal in current condition using adaptation General Electric's Matrix into Internal External Matrix. Below is the quantification of Aqiqah Al-Hilal's SWOT variables.

Based on the table above the total score of internal factor evaluation is 2.93. This condition puts the Aqiqah Al-Hilal's internal factors in the middle between high (score is 4) and low (score is 1 ). The Next step is the external factor.

TABLE I: SWOT ANALYSIS FOR AQIQAH AL-HILAL (AUTHOR'S ANALYSIS)

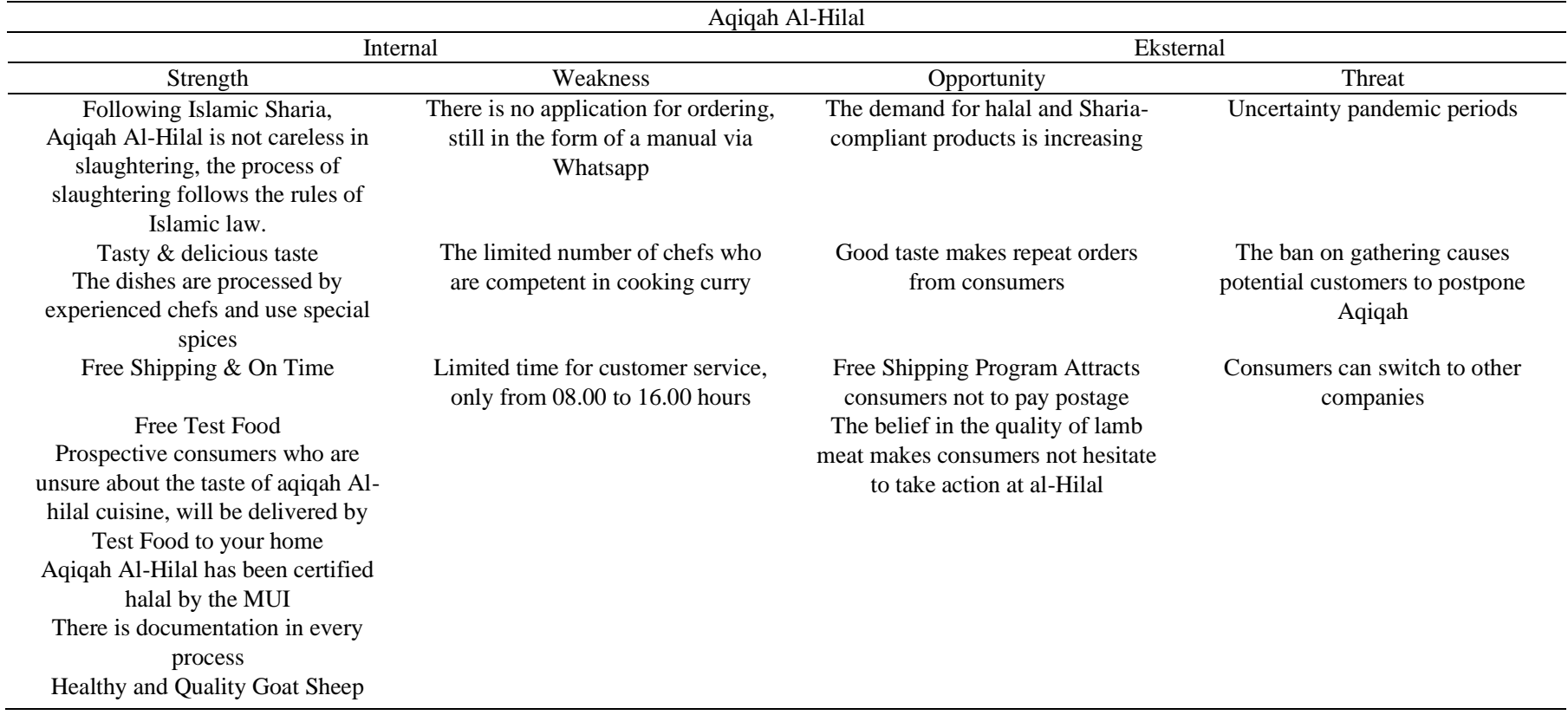

TABLE II: QUANTIFICATION OF INTERNAL FACTOR EVALUATION OF AQIQAH AL-HILAL (AUTHOR'S ANALYSIS BASED ON INTERVIEW AND FGD)

\begin{tabular}{|c|c|c|c|c|}
\hline No & $\begin{array}{c}\text { Strength } \\
\end{array}$ & Rating & Weight & Total Score \\
\hline 1 & $\begin{array}{l}\text { Following Islamic Sharia, Aqiqah Al-Hilal is not careless in slaughtering, the } \\
\text { process of slaughtering follows the rules of Islamic law. }\end{array}$ & 4 & 0,12 & 0,48 \\
\hline 2 & $\begin{array}{l}\text { Tasty \& delicious taste } \\
\text { The dishes are processed by experienced chefs and use special spices }\end{array}$ & 4 & 0,15 & 0,6 \\
\hline 3 & $\begin{array}{l}\text { Free Shipping \& On Time, } \\
\text { Free Test Food }\end{array}$ & 4 & 0,08 & 0,32 \\
\hline 4 & $\begin{array}{l}\text { Prospective consumers who are unsure about the taste of aqiqah Al-hilal cuisine, } \\
\text { will be delivered by Test Food to your home }\end{array}$ & 3 & 0,08 & 0,24 \\
\hline 5 & Aqiqah Al-Hilal has been certified halal by the MUI & 3 & 0,14 & 0,42 \\
\hline 6 & There is documentation in every process & 3 & 0,1 & 0,3 \\
\hline 7 & Healthy and Quality Goat Sheep & 3 & 0,12 & 0,36 \\
\hline No & Weaknesses & Rating & Weight & Total Score \\
\hline 1 & There is no application for ordering, still in the form of a manual via Whatsapp & 1 & 0.05 & 0,05 \\
\hline 2 & The limited number of chefs who are competent in cooking curry & 1 & 0.08 & 0,08 \\
\hline 3 & Limited time for customer service, only from 08.00 to 16.00 hours & 1 & 0.08 & 0,08 \\
\hline & TOTAL & & 1.0 & 2.93 \\
\hline
\end{tabular}


TABLE III: QUANTIFICATION OF EXTERNAL FACTOR EVALUATION OF AQIQAH AL-HILAL (AUTHOR'S ANALYSIS BASED ON INTERVIEW AND FGD)

\begin{tabular}{|c|c|c|c|c|}
\hline No & Opportunities & Rating & Weight & Total Score \\
\hline 1 & $\begin{array}{l}\text { The demand for halal and } \\
\text { Sharia-compliant products is } \\
\text { increasing }\end{array}$ & 4 & 0,15 & 0,6 \\
\hline 2 & $\begin{array}{l}\text { Good taste makes repeat orders } \\
\text { from consumers }\end{array}$ & 3 & 0,14 & 0,42 \\
\hline 3 & $\begin{array}{l}\text { Free Shipping Program } \\
\text { Attracts } \\
\text { postage }\end{array}$ & 2 & 0,14 & 0,28 \\
\hline 4 & $\begin{array}{l}\text { The belief in the quality of } \\
\text { lamb meat makes consumers } \\
\text { not hesitate to take action at al- } \\
\text { Hilal }\end{array}$ & 3 & 0,15 & 0,45 \\
\hline No & Threat & Rating & Weight & Total Score \\
\hline 1 & $\begin{array}{l}\text { Uncertainty pandemic periods } \\
\text { The ban on gathering causes }\end{array}$ & 3 & 0,15 & 0,45 \\
\hline 2 & $\begin{array}{l}\text { potential customers to postpone } \\
\text { Aqiqah }\end{array}$ & 3 & 0,15 & 0,45 \\
\hline \multirow[t]{2}{*}{3} & $\begin{array}{l}\text { Consumers can switch to other } \\
\text { companies }\end{array}$ & 2 & 0,12 & 0,24 \\
\hline & TOTAL & & 1.00 & 2.89 \\
\hline
\end{tabular}

According to the table EFE, Aqiqah Al-hilal's external factors score is 2,89 . This condition also places Aqiqah alhilal in the middle zone almost similar to internal factors. Using the adaptation internal-external matrix from GE's matrix we can understand where the Aqiqah Al-hilal current condition and what method should Aqiqah Al-hilal to do for business strategy during the pandemic and in the new normal era.

\section{CONCLUSION}

Based on the results of the finding and analysis of the business conditions of Aqiqah Al-Hilal, the position of Aqiqah Al-Hilal in the current situation will determine the strategies that need to be taken to survive the pandemic. The results of the IE matrix with IFE (2.99) and EFE (2.89) show that Aqiqah Al-Hilal is in the Hold and Maintain position. In the "Hold and Maintain" position, the best strategy to do is market penetration and product development.

IFE

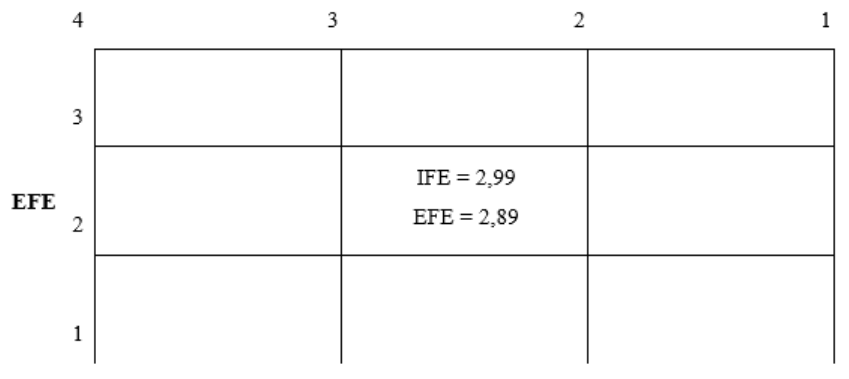

Category: Hold and Maintain Strategy: Market penetration, product development

Fig. 2. IE Matrix of Aqiqah Al-Hilal (Author's Analysis, 2021).

Based on the conditions of the company Aqiqah Al-Hilal, the elaboration of a fit market penetration and product development strategy implemented by Aqiqah Al-Hilal during the pandemic and new normal era are as follows.

\section{A. Market Penetration Strategy; First Alternative Solution}

Market penetration strategy can be a solution to boost Aqiqah Al-Hilal's more optimal profits in a short time. As the name implies, market penetration is one of the company's methods in developing market share for a particular product or service. In this case, the market penetration strategy that Aqiqah Al-Hilal can do is as follows:

\section{1) Increased promotion}

The promotion of goods or services from Aqiqah Al-Hilal is an important strategy for market penetration, and the impact can be significant if done properly. At least, the brand awareness of Aqiqah Al-Hilal will increase. Increasing the promotion of Aqiqah Al-Hilal can be done by conducting long and short-term campaigns depending on the needs and funds in Aqiqah Al-Hilal's finances. However, keep in mind that this should only be done after careful planning to produce satisfactory results.

2) Price adjustments through Aqiqah Package Variations

One of the most widely used strategies for market penetration is price adjustment. In this context, Aqiqah AlHilal can carry out a price adjustment strategy by offering a more varied Aqiqah package. If previously there were only 3 packages, to optimize market penetration, Aqiqah Al-Hilal could add to 5 packages so that potential consumers could have choices ranging from the lowest to the highest price. A price adjustment can mean a decrease or an increase in prices. A change in price, either a decrease or an increase after the analysis of Aqiqah Al-Hilal's competitors' products is a good market penetration tactic.

\section{3) Improving the quality of products and services}

To be liked by potential consumers, Aqiqah products and services must of course have good quality. Aqiqah Al-Hilal is well known for its delicious quality of cuisine, this must be maintained so that consumers can repeat orders or recommend Aqiqah to friends or relatives. Apart from products, services must also be continuously improved. The Aqiqah Al-Hilal team must think about a strategy to improve the quality of customer service so that they can be served not only during working hours but can serve 24 hours. For example, with the help of using chatbots or optimization of WA marketing. Improving the quality of products and services also affects the market penetration ability of a business.

\section{4) Optimization of distribution channels}

To ensure successful market penetration, Aqiqah Al-Hilal must know the right distribution channels to distribute Aqiqah products. At present, Aqiqah Al-Hilal must find new channels so that sales increase from time to time. Examples of channels that can be considered today are email marketing, telemarketing, internet marketing, and others.

\section{B. Product Development Strategy; Second Alternative Solution}

The second strategy that Aqiqah Al-Hilal can do is to develop products and introduce them to existing markets. A product development strategy is an effort to provide product 
choices to consumers. Indeed, this has risks. Because consumers who are familiar with old products are then treated to new products that they are not familiar with. It takes efforts to introduce new products to consumers.

The focus that Aqiqah Al-Hilal must do on this strategy is to create new products or modify old products and make them have more value than existing ones. The steps that can be taken in the Aqiqah Al-Hilal product development strategy are as follows:

\section{1) Diversification of processed lamb meat products}

Based on internal analysis, Aqiqah Al-Hilal is partnering with many sheep breeders around Bandung Raya. So far, Aqiqah Al-Hilal only provides Aqiqah packages in the form of mutton satay and curry. It is time, in current conditions, Aqiqah Al-Hilal can diversify its processed goat meat products. One way that can be done is to make processed lamb meat in the form of Lamb Rendang. If usually Rendang is only known as processed beef, now meat processing companies have started making Lamb Rendang. This is an opportunity for Aqiqah Al-Hilal to be able to sell products other than those that already exist. Rendang Domba is an innovation in the processing of lamb to make it more practical and durable. Product development with Rendang Domba can add new market segments and customers from Aqiqah Al-Hilal so that it can be one of the solutions to increase Aqiqah Al-Hilal's revenue.

2) Adding value with a variety of merchandise on the Aqiqah Package

After intensive FGD with Aqiqah Al-Hilal stakeholders as well as a comprehensive analysis of the Aqiqah Al-Hilal business. Sales of Aqiqah Al-Hilal have increased when the company promotes by adding merchandise to the Aqiqah package. The merchandise includes a wall clock, Aqiqah certificate, and a unique frame for the certificate. Adding value to the variety of merchandise in the Aqiqah Package can also be done by giving a tumbler to consumers where the tumbler can be customized with a child's photo of Aqiqah Al-Hilal so that it is more exclusive and has value as a keepsake

\section{3) Adding new types of business}

Aqiqah al-hilal has been established 8 years ago, namely in October 2013. During that time, the type of business operated was only Aqiqah services. In facing a situation full of uncertainty like now, it is time for Aqiqah Al-Hilal to venture into a new business. One of the new business alternatives is as a catering provider for boxed rice or events. Armed with 8 years of experience in Aqiqah service, it seems that being a catering provider is not a difficult thing for the Aqiqah Al-Hilal team to do. This is an optimization of all the resources possessed by Aqiqah Al-Hilal, starting from competent and trained chefs and marketing human resources who are willing to learn in dealing with business situations and can continue to adapt to uncertainties.

Besides that, Aqiqah Al-Hilal can also sell sheep directly for Qurban purposes. The sale of sheep for sacrifices can be carried out by the Aqiqah Al-Hilal Team as an alternative to adding new customers so that they can increase revenue from Aqiqah Al-Hilal.

\section{REFERENCES}

Aaker, David. (2012, p. 124) Manajemen Pemasaran Strategi. $8^{\text {th }}$ ed. Jakarta: Salemba Empat.

Aaker, David. (2013, p. 84). Manajemen Pemasaran Strategi. $8^{\text {th }}$ ed. Jakarta: Salemba Empat.

Aqiqah (aqiqa, akika) (2021, March 18) - celebrate the birth of your child, https://islamicaid.com/aqiqah/.

Fika Nurul Ulya. (2021, March 16) Dunia Usaha Terdampak Covid-19 Sektor-sektor Ini yang Jatuh Paling Dalam. https://money.kompas.com/read/2020/07/13/124000526/dunia-usahaterdampak-covid-19-sektor-sektor-ini-yang-jatuh-paling-dalam

Internal data of aqiqah Al-Hilal. (2021, August 18) source from documentation and interview with stakeholder of Aqiqah Al-Hilal.

Internal data of aqiqah Al-Hilal. (2021, August 18) source from documentation.

Iswanto Anas (2020). Problematika Ekonomi dan Pandemi Covid-19, Bunga Rampai Karya Tulis Seperempat Abad Program Doktor Ilmu Ekonomi Feb-Unhas.

Jenti Jay, (2021, August 17) Peluang Bisnis Katering Akikah yang Raup Untung. https://mediaini.com/bisnis/2021/05/23/39548/peluangbisnis-catering-akikah-yang-raup-untung/.

Joewono. (2012, p. 3) Strategy Management. Jakarta: Arrbe.

Joewono. (2012, p. 4) Strategy Management. Jakarta: Arrbe.

Maleong, L.J. (2011, p. 6). Metodologi Penelitian Kualitatif Edisi Revisi. Bandung: PT. Remaja Rosdakarya.

Rasheda L. Weaver. (2021, September 8) The Impact of COVID-19 on the Social EnterpriseSector, Journal of Social Entrepreneurship, 2020, p7 https://doi.org/10.108.

Rasheda L. Weaver (2020, p. 8): The Impact of COVID-19 on the Social EnterpriseSector, Journal of Social Entrepreneurship, article: https://doi.org/10.108.

Ratten, V. 2020a. (2021, September 8) Coronavirus (Covid-19) and Social Value co-Creation. International Journal of Sociology and Social Policy. https;//doi:10.1108/IJSSP-06-2020-0237.

The Internal-External Matrix. (2021, August 28) Copyright (C 2013 Pearson Education, Inc. publishing as Prentice Hall, https://slidetodoc.com/strategy-analysis-and-choice-chapter-sixchapter-objectives].

Wandebori, (2019, p192). Manajemen Strategy dalam Perspektif Indonesia; ITB Press.

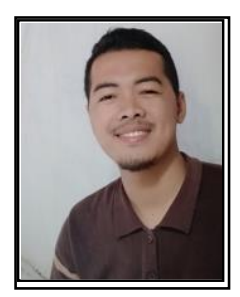

Isep Paozi is an MBA Candidate from SBM ITB, currently working as Empowerment and Volunteer Manager at Laz Al-Hilal Bandung. Enthusiast in community development, Corporate Social Responsibility, Sustainability Development, Business Development and Social Entrepreneurship. Apart from being an MBA Candidate, he is also the owner of Kreasy Muamalah, a small business engaged in selling electronic goods and furniture using the sharia credit system.

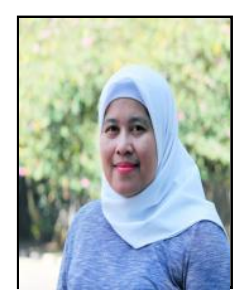

Melia Famiola is a Lecturer at SBM ITB, currently she serves as Assistant Professor at SBM ITB with Entrepreneurship and Technology Management Interest Group. Her research interests are related to CSR, sustainable business, social entrepreneurship and eco-preneurship. In addition to her activities as a lecturer, he is the founder of the Teras which is a social enterprise to support the sustainability of the city program. 